DOI : $10.24850 / \mathrm{j}$-tyca-2022-01-04

Articles

\title{
Treatment of domestic wastewater using activated carbon prepared from sugarcane bagasse
}

\section{Tratamiento de aguas residuales domésticas utilizando carbón activado preparado de bagazo de caña de azúcar}

Ebelia Del Angel ${ }^{1}$, ORCID: https://orcid.org/0000-0002-6567-4263

Mayra Agustina Pantoja2, ORCID: https://orcid.org/0000-0001-71167500

Rosendo López³, ORCID: https://orcid.org/0000-0002-6850-8973

Alida Elizabeth Cruz ${ }^{4}$, ORCID: https://orcid.org/0000-0001-7216-2699

1Universidad Juárez Autónoma de Tabasco, Academic Division of Engineering and Architecture, Cunduacán, Tabasco, Mexico, ebelia.delangel@ujat.mx

2Universidad Juárez Autónoma de Tabasco, Academic Division of Engineering and Architecture, Cunduacán, Tabasco, México, mayra.pantoja@ujat.mx 
3Universidad Juárez Autónoma de Tabasco, Academic Division of Engineering and Architecture, Cunduacán, Tabasco, Mexico, rosendo.lopez@ujat.mx

4Universidad Juárez Autónoma de Tabasco, Academic Division of Engineering and Architecture, Cunduacán, Tabasco, Mexico, alida.cruz@ujat.mx

Corresponding author: Ebelia Del Angel-Meraz, ebelia.delangel@ujat.mx

\section{Abstract}

Solid residues of sugar cane industry represent one of the major agroresidues. They are often considered as waste; however, they can be used as an inexpensive raw material for different applications, including production of activated carbon (CA) to be used as adsorbent in sustainable processes. On the other hand, domestic wastewater contains grease and oil residues, which causes pipe plugging. Adsorption of these compounds is possible with activated carbon. In this work, CA was obtained from sugarcane bagasse residues through a simplified two steps method: chemical activation with $\mathrm{H}_{3} \mathrm{PO}_{4}$ and pyrolysis at $973 \mathrm{~K}$. Textural and structural characterizations were performed by $\mathrm{N}_{2}$ physisorption, scanning electron microscopy (SEM) and X-ray diffraction (XRD). Carbon samples $\left(\mathrm{S}_{\mathrm{BET}}=914 \mathrm{~m}^{2} \mathrm{~g}^{-1}\right)$ showed a structure analogous to graphite and microporous surface characteristics of activated carbon. The adsorption of oils from domestic wastewater was evaluated with the synthesized 
carbon. Results showed that after eight hours, the sugarcane bagasse activated carbon adsorbed $94 \%$ of the oils contained in wastewater. These data are similar to the adsorption process carried out in a commercial activated carbon (96\%). In this work also adsorption kinetics were evaluated with pseudo first-order, pseudo second order, and intraparticle equations, the experimental data showed a betterfit with the pseudo second order model and to the Langmuir isotherm. These results prove the fact we can add value to sugarcane bagasse residues to efficiently remove greases and oils from wastewater.

Keywords: Activated carbon, grease and oils, sugarcane bagasse, wastewater.

\section{Resumen}

Los residuos de la industria de la caña de azúcar representan uno de los principales agro-residuos. A menudo se consideran como basura y se pueden utilizar como materia prima barata para obtener carbón activado (CA). Por otra parte, el agua residual doméstica contiene residuos de grasas y aceites causantes del taponamiento de las tuberías; se puede lograr la adsorción de estas sustancias con carbón activado. En este trabajo se obtuvo CA a partir de residuos de bagazo de caña de azúcar mediante un método simplificado de dos pasos: activación química con $\mathrm{H}_{3} \mathrm{PO}_{4}$ y pirólisis a $973 \mathrm{~K}$. La caracterización textural y estructural fue por fisisorción $\mathrm{N}_{2}$, microscopía electrónica de barrido (SEM) y difracción de rayos $X(R D X)$. El carbono obtenido ( $S_{B E T}$ de $914 \mathrm{~m}^{2} \mathrm{~g}^{-1}$ ) mostró una estructura análoga al grafito y una superficie microporosa característica 
de los carbonos activados. El carbono sintetizado se evaluó en la adsorción de grasas y aceites de aguas residuales domésticas. Los resultados mostraron el valor agregado que se obtiene del bagazo de caña para eliminar eficientemente grasas y aceites de aguas residuales, ya que después de ocho horas se encontró que su CA adsorbió el $94 \%$ de las grasas y aceites contenidas en las aguas residuales, lo cual es similar a la adsorción de un CA comercial (96\%). También se evaluó la cinética de adsorción con las ecuaciones de pseudo primer orden, pseudo segundo orden e intrapartícula; los datos experimentales mostraron un mejor ajuste con el modelo de pseudo segundo orden.

Palabras clave: carbón activado, grasas y aceites, bagazo de caña de azúcar, agua residual.

Received: $11 / 03 / 2020$

Accepted: 01/01/2021

\section{Introduction}

Adsorbents from natural sources have received special attention over the past fifty years, since the materials used are considered to be 
environmentally friendly. These show a high activity in the decontamination of wastewater with a low consumption of chemical reagents for preparation. Among all natural adsorbents, activated carbon is the most promising material due to the availability of raw material for production including biomass, where several precursors have been reported, for example: coconut shell, rice husk, palm leaves, wood bark, peanut peel or other materials containing lignin, cellulose and hemicellulose.

The adsorption nature of activated carbon is different, not only by the biomass source, but also by the chemical procedure used for its production (Garg, Amita, Kumar, \& Gupta, 2004; Velázquez-Trujillo, Bolaños-Reynoso, \& Pliego-Bravo, 2010; Hajira, Muhammad, Nasir, Uzma, \& Tahreem, 2016; Corral-Escárcega et al., 2017; RamírezRodríguez, Reyes-Ledezma, Chávez-Camarillo, Cristiani-Urbina, \& Morales-Barrera, 2018; Almeida et al., 2019). Remarking differences related with the purification practices such as distillation, crystallization and solvent extraction, adsorption allows the removal of trace contaminants because their polar nature allows a strong bonding with polar and organic molecules on their surface.

The textural and structural properties of activated carbon, useful for the treatment of wastewater due to the textural and structural properties of activated carbon. For many adsorption applications such as the removal of metal ions (Garoma \& Badriyha, 2010; Izzeldin, Bice, Ngilaa, \& Nyamoria, 2013; Kuncoro, Dwi, Handoko, Oktiani, \& Septya, 2018a; Kuncoro, Mitha-Isnadina, Darmokoesoemo, Dzembarahmatiny, \& 
Kusuma, 2018b) or protein purification, the purity of activated carbons takes a special relevance (Cruz, Ainassaari, Gómez, Solís, \& Keiski, 2018; Andrade et al., 2018).

Moreover, polar nature of carbons allows organic and polar molecules to bind strongly to their surface, due to this property, they can be considered as an almost universal adsorbent. In the field of water treatment, activated carbon acts as an effective and economical adsorbent with multiple effects improving the taste and odor of water, removing contaminants (Leyva-Ramos, Díaz-Flores, Guerrero-Coronado, Mendoza-Barrón, \& Aragón-Piña, 2004; Ramavandi, Asgari, Faradmal, Sahebi, \& Roshani, 2014; Leyva-Ramos, Rivera-Utrilla, Medellin-Castillo, \& Sánchez-Polob, 2010; Goswami \& Phukan 2017; Ghani, Yusoff, Zaman, Zamri, \& Andas, 2017; Islam, Ahmed, Khanday, Asif, \& Hameed, 2017).

Nowadays the Sugar Industry produce one ton of sugarcane bagasse per ton of refined sugar, and a portion of this bagasse is used as fuel for boilers or sold to the paper industry (Meza, Lomascolo, \& Laurence, 2006). However, the disposal and confinement of the remaining waste becomes a serious environmental control problem. Some research has focused on the use of sugarcane bagasse to remove greases and oils and hydrocarbons. The most recent study is Almeida et al. (2019), which performed the adsorption of emulsified petroleum present in a synthetic wastewater, with cane bagasse, managing to eliminate $90 \%$. Most studies focus on the elimination of petroleum hydrocarbons using sugarcane bagasse as biosorbent, without transforming it into activated carbon (Leiva-Mass, Martínez-Nodal, Esperanza-Pérez, Rodríguez-Rico, \& 
Gordiz-García, 2012; Acosta, 2013; Rincones-Poyer, Valladares, DangladFlores, \& Salazar-Palencia, 2015). In this investigation, activated carbon made from sugarcane bagasse is synthesized and characterized to assess its efficiency in the removal of domestic wastewater greases and oils respect to commercial carbon.

\section{Materials and methods}

\section{Activated carbon synthesis}

The sugarcane bagasse was obtained from the Ingenio Benito Juárez Presidente, located in Cárdenas, Tabasco, Mexico. The raw material was washed to remove residual inorganic substances, then dried at environmental conditions for three days. The samples were activated in a medium acid $\left(\mathrm{H}_{3} \mathrm{PO}_{4}-1.8 \mathrm{M}\right)$ for $48 \mathrm{~h}$ (Mateo-Sánchez, 2011), followed by a carbonization process at $973 \mathrm{~K}$ for $1 \mathrm{~h}$ in a muffle. The resulting carbon was washed with distilled water at a temperature of $343 \mathrm{~K}$ using a $\mathrm{NaOH}$ solution $(0.1 \mathrm{M})$, until a valued of $\mathrm{pH} 6$, dried then in a mufla at $373 \mathrm{~K}$ for $8 \mathrm{~h}$ (Figure 1). 
Tecnología y

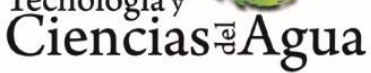

2022, Instituto Mexicano de Tecnología del Agua

Open Access bajo la licencia CC BY-NC-SA 4.0

(https://creativecommons.org/licenses/by-nc-sa/4.0/)

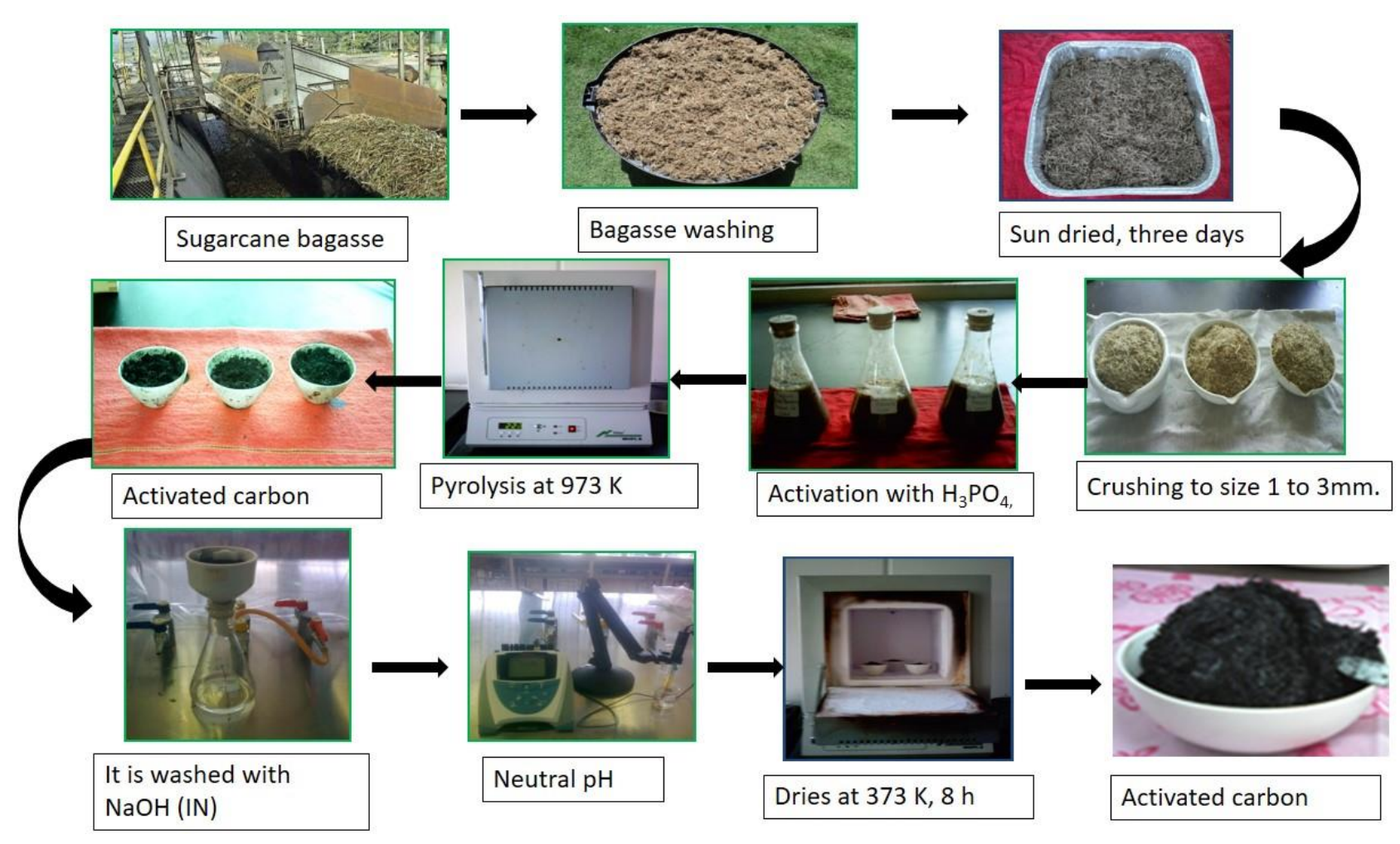

Figure 1. Synthesis of activated carbon from sugarcane bagasse.

\section{Characterization of activated carbon}

Diffraction patterns of carbon powder was performed on an X-ray equipment (XDR), recorded in the range $20^{\circ} \leq 2 \theta \leq 80^{\circ}$ using a Phillips $X ' P e r t$ diffractometer, radiation CuK $(-1.5406 \AA)$ and a goniometer speed 
of $1^{\circ}\left(2 \mathrm{~min}^{-1}\right)$. The micrographs of activated carbon were obtained in a JEOL JSM-6010LA scanning electron microscope with EDS detector (SEMEDS).

For the measurement of the isoelectric point (potential $Z$ vs. $\mathrm{pH}$ ) a solution of $0.05 \mathrm{mg}$ of activated carbon in $10 \mathrm{ml}$ of deionized water was prepared. Subsequently, it was dispersed in an ultrasonic processor and analyzed in the Zetasizer Nano ZS equipped with an automatic titrator using an $\mathrm{HCl}$ solution of $0.5 \mathrm{M}$ and $0.25 \mathrm{M}$ of $\mathrm{NaOH}$.

Specific surface area, pore volume and pore size distribution of activated carbon were obtained from $\mathrm{N}_{2}$ adsorption using conventional BET methods in a TriStar II Micromeritics. Measurements were performed at the normal boiling temperature of $\mathrm{N}_{2}$ at a temperature of $77 \mathrm{~K}$ and at atmospheric pressure.

\section{Greases and oils adsorption tests}

The wastewater samples were collected from the drainage network of the dining room building located in the Academic Division of Engineering and Architecture of the Juarez Autonomous University of Tabasco in the town of Cunduacán in Tabasco State. Adsorption tests were carried out in different batches process, in which 1 gram of activated carbon was added 
and dispersed in 1 liter of wastewater. Then, samples were taken in triplicate at different times of $0.5,1,8,24$ and $48 \mathrm{~h}$. After that, to determine the greases and oils content the NMX-AA-005-SCFI-2000 standard was applied. Then, the adsorption capacity of activated carbon made from cane bagasse (BAC) was compared with commercial activated carbon (CAC-Repsol brand), under the same reaction conditions described above. CAC and BAC adsorption capacity $\left(q_{t}\right)$ in $\mathrm{mg} / \mathrm{g}$ was calculated according to Equation (1):

$q_{t}=\left(C_{o}-C_{t}\right) v / w$

Where:

$C_{O}=$ Initial concentration of grease and oil into the wastewater mixture $(\mathrm{mg} / \mathrm{l})$.

$C_{t}=$ Concentration of grease and final oil in the liquid phase $(\mathrm{mg} / \mathrm{l})$.

$v=$ Volume used of wastewater used (I).

$w=$ Mass of the adsorbent $(\mathrm{g})$.

The models evaluated in adsorption kinetics were (Table 1): pseudo first order, pseudo second order, and intraparticle diffusion model (Almeida et al., 2019; Kuncoro et al., 2018a; Kuncoro et al., 2018b; Corral-Escárcega et al., 2017; Andrade et al., 2018; Ramírez-Rodríguez et al., 2018; Saad, Isa, \& Bahari, 2010; Izzeldin et al., 2013). 
Tecnología y

Ciencias $₫$ Agua
2022, Instituto Mexicano de Tecnología del Agua

Open Access bajo la licencia CCBY-NC-SA 4.0

(https://creativecommons.org/licenses/by-nc-sa/4.0/)

Table 1. Kinetic models and isotherms to evaluate CAC and BAC.

\begin{tabular}{|c|c|c|c|c|}
\hline Model & Equation & Plotting & $\begin{array}{c}\text { Equation } \\
\text { number }\end{array}$ & References \\
\hline $\begin{array}{c}\text { Pseudo first } \\
\text { order }\end{array}$ & $\begin{array}{l}\ln \left(q_{e}-q_{t}\right) \\
=\ln q_{e}-K_{1} t\end{array}$ & $\ln \left(q_{e}-q_{t}\right) v s t$ & (2) & $\begin{array}{c}\text { Lagergren } \\
\text { (1898) }\end{array}$ \\
\hline $\begin{array}{l}\text { Pseudo } \\
\text { second } \\
\text { order }\end{array}$ & $\frac{t}{q_{t}}=\frac{1}{K_{2} q_{e}^{2}}+\frac{1}{q_{e} t}$ & $\frac{t}{q_{t}} v s t$ & (3) & $\begin{array}{c}\text { Ho \& McKay } \\
\text { (1998) }\end{array}$ \\
\hline $\begin{array}{c}\text { Intraparticle } \\
\text { diffusion }\end{array}$ & $q_{t}=K_{\text {int }} t^{0.5}+C$ & $q_{t} v s t^{0.5}$ & (4) & $\begin{array}{c}\text { Weber \& } \\
\text { Morris } \\
(1963)\end{array}$ \\
\hline $\begin{array}{l}\text { Langmuir } \\
\text { isotherm }\end{array}$ & $\frac{C_{e}}{q_{e}}=\frac{1}{q_{m} K L}+\frac{1}{q_{m} C_{e}}$ & $\frac{C_{e}}{q_{e}} v s C_{e}$ & (5) & $\begin{array}{l}\text { Langmuir } \\
(1918)\end{array}$ \\
\hline $\begin{array}{l}\text { Freundlich } \\
\text { isotherm }\end{array}$ & $\begin{array}{l}\log q_{e} \\
=\log K_{f}+\frac{1}{n \log C_{e}}\end{array}$ & $\log q_{e} v s \log C_{e}$ & (6) & $\begin{array}{l}\text { Freundlich } \\
\text { (1906) }\end{array}$ \\
\hline
\end{tabular}

\section{Results and discussion}




\section{Characterization of activated carbon}

\section{X-ray diffraction}

The diffractogram of Figure $2 \mathrm{a}$ and Figure $2 \mathrm{~b}$ correspond to the BAC and CAC. The presence of a typical amorphous carbon at $2 \theta$ to $28^{\circ}, 34^{\circ}, 38^{\circ}$ and $50^{\circ}$ is observed. This diffractogram also shows two corresponding asymmetric peaks at $2 \theta$ to $15^{\circ}$ and $55^{\circ}$, which are assigned to graphite, (Contreras et al., 2008; Adinaveen, Kennedy, Vijaya, \& Sekaran, 2013).

Graphite peaks are well defined, identifying that activated carbon has two types of porous structures characteristic of these materials: the first type corresponds to a graphite-like microcrystalline structure consisting of parallel layers of hexagonally arranged carbon atoms. Meanwhile the second type is described as a three-dimensional lattice of disordered carbon hexagons due to the formation of benzene structures formed during the carbonization process (Almeida et al., 2019). On the other hand, Figure $2 \mathrm{~b}$ corresponds to commercial carbon (CAC) shows a single much defined peak related to a fullerene structure, and this type is the third most stable form of carbon, after diamond and graphite. 


\section{2, Instituto Mexicano de Tecnología del Agua}

Tecnología y

Ciencias $\approx$ Agua
Open Access bajo la licencia CC BY-NC-SA 4.0

(https://creativecommons.org/licenses/by-nc-sa/4.0/)
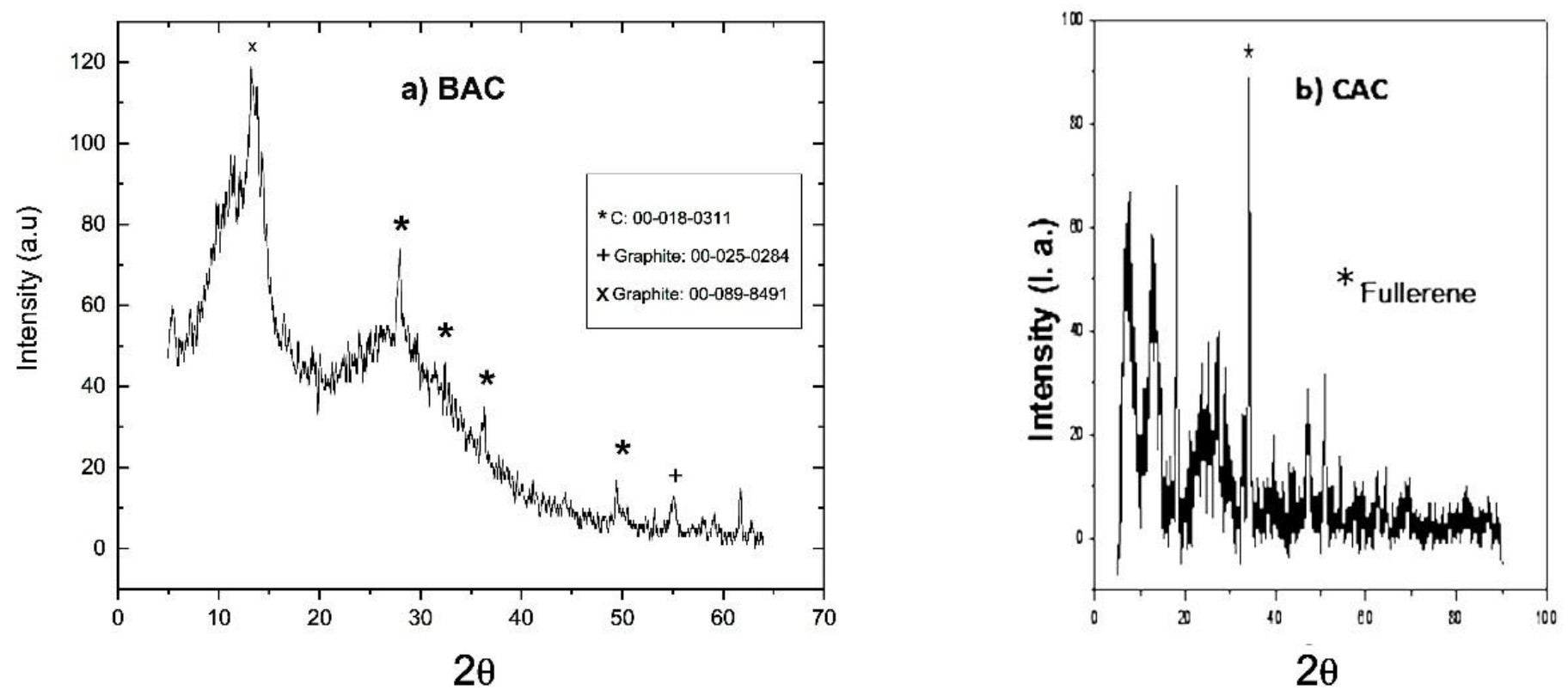

Figure 2. Diffractogram of a) BAC and b) CAC.

\section{Scanning Electron Microscopy (SEM)}

Figure 3a shows the morphology of the BAC before being used for wastewater treatment, the amorphous arrangement of carbon plates with micropores is observed forming in the spaces between them. The presence of elongated fibers in the sugarcane bagasse sample ensures they can take part in adsorption processes. Yun, Liu and Zhang (2010) reported this structure is due to the presence of bonded fibers, probably 
due to the presence of hemicellulose and lignin. The Dispersive Energy $X-$ ray Spectroscopy (EDS) analysis is shown below in order from highest to lowest the elements that make up the sample \% mass; C $(64.53 \%)>0$ $(26.29 \%)>\mathrm{P}(4.64 \%)>\mathrm{Si}(2.96 \%)>\mathrm{Na}(1.88 \%)$, the presence of $\mathrm{P}$ is due to the use of phosphoric acid for the activation of the material, the presence of sodium is due to the use of sodium hydroxide for the neutralization of activated carbon. Figure $3 \mathrm{~b}$ shows the BAC after 8-hour treatment, it is observed that the surface of the material is porous and have different sizes, pores of the material and can aid in the internal diffusion and adsorption of greases and oils. The Dispersive Energy X-ray Spectroscopy (EDS) analysis is shown below in order from highest to lowest the elements that make up the sample in \% in mass; C $(78.46 \%)$ $>\mathrm{O}(18.28 \%)>\mathrm{P}(1.45 \%)>\mathrm{Si}(0.83 \%)>\mathrm{Ca}(0.27 \%), \mathrm{S}(0.18 \%)>$ $\mathrm{Cu}(0.53 \%)$. 
Tecnología y

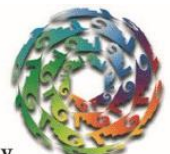

Ciencias ฐึgua
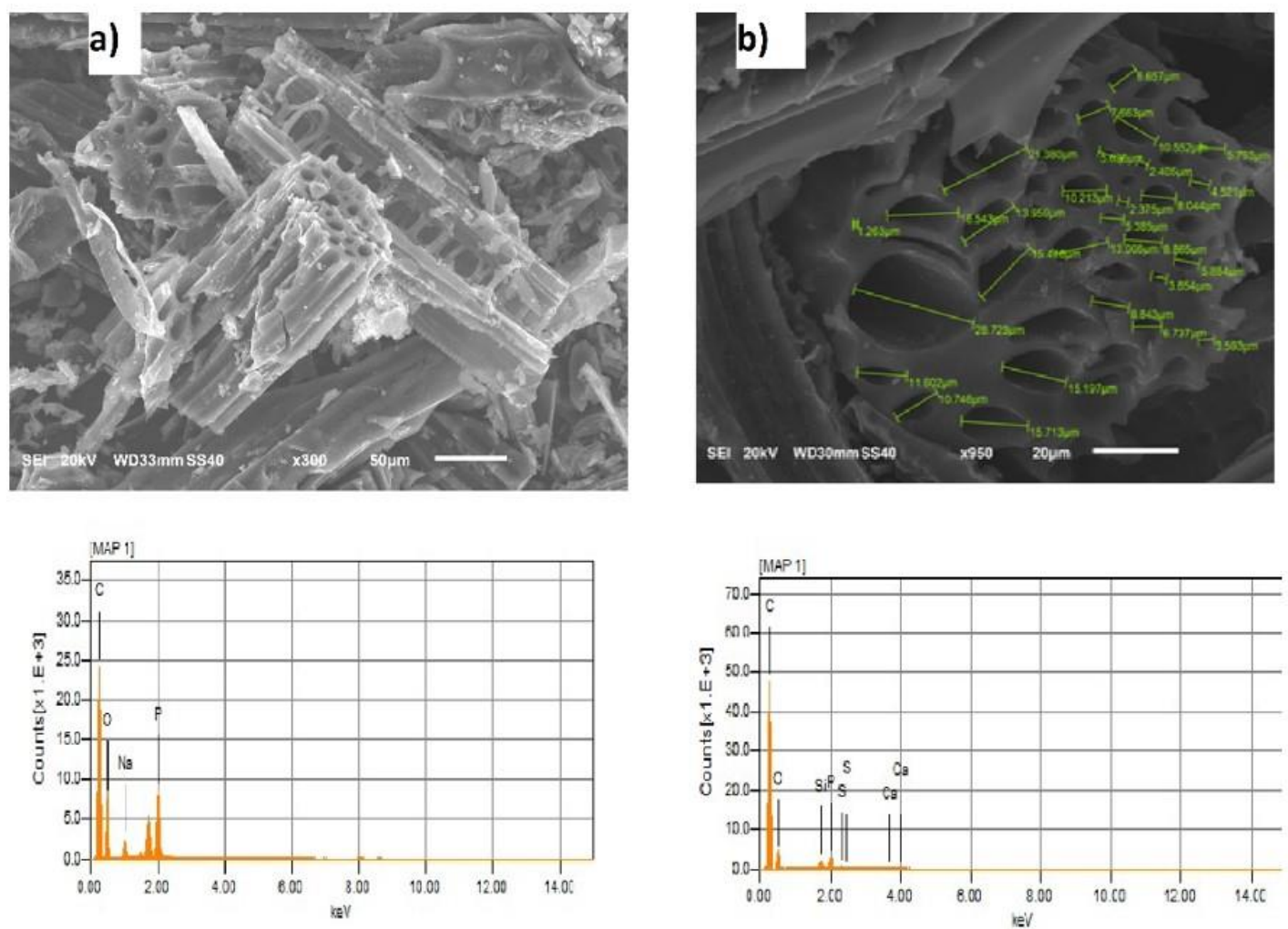

2022, Instituto Mexicano de Tecnología del Agua

Open Access bajo la licencia CC BY-NC-SA 4.0

(https://creativecommons.org/licenses/by-nc-sa/4.0/)

a) Before the experiment

\begin{tabular}{|l|l|l|}
\hline Element & \% mass & \% mole \\
\hline $\mathrm{C}$ & 64.53 & 73.32 \\
\hline $\mathrm{P}$ & 4.64 & 2.05 \\
\hline 0 & 26.29 & 22.42 \\
\hline $\mathrm{Na}$ & 1.58 & 0.94 \\
\hline $\mathrm{Si}$ & 2.96 & 1.27 \\
\hline Total & 100.00 & 100.00 \\
\hline
\end{tabular}

b) At $8 \mathrm{~h}$ of wasterwater treatment

\begin{tabular}{|l|l|l|}
\hline Element & $\%$ mass & mole \\
\hline $\mathrm{C}$ & 78.46 & 84.05 \\
\hline $\mathrm{P}$ & 1.45 & 0.60 \\
\hline $\mathrm{O}$ & 18.28 & 14.70 \\
\hline $\mathrm{Ca}$ & 0.27 & 0.09 \\
\hline $\mathrm{Si}$ & 0.83 & 0.38 \\
\hline $\mathrm{Cu}$ & 0.53 & 0.11 \\
\hline $\mathrm{S}$ & 0.18 & 0.07 \\
\hline Total & 100.00 & 100.00 \\
\hline
\end{tabular}

Figure 3. SEM micrographs of sugarcane bagasse BAC: a) Before the experiment; b) At $8 \mathrm{~h}$ of wastewater treatment.

\section{Isoelectric point of activated carbon BAC}


The zero-load point (ZCP) and the isoelectric point (IEP) of the adsorbent allow to determine the overall distribution of the load on its surface and, therefore, the ability to retain contaminants. The zero load point indicates the most appropriate $\mathrm{pH}$ value range to achieve efficient removal of a given anionic or cationic contaminant. On the other hand, the zeta potential (ZP) is determined by the nature of the particle surface and the dispersion medium. The Figure 4 shows the $Z$ potential of the BAC sample depending on the $\mathrm{pH}$. The zero-load point intercepts the isoelectric point at a $\mathrm{pH}$ of 2.50 .

Isoelectric Ttration Graph

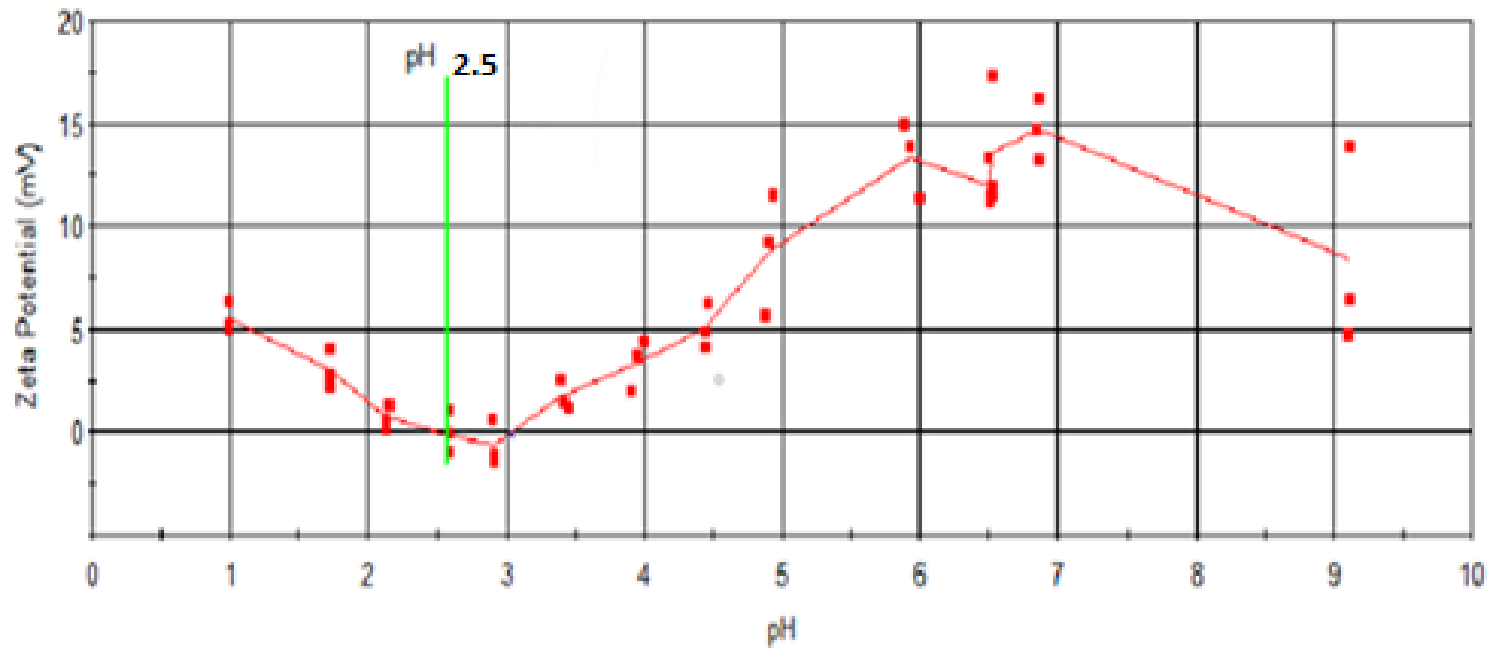

- Zeta Potential (M7 - H3PO4) Isoelectric Point (1.77+H3PO4)

Figure 4. The $\mathrm{Z}$ potential of $\mathrm{BAC}$ as a function of $\mathrm{pH}$. 
In the IEP, particles do not experience repulsion, there may be some attraction between particles near this value. Because the ZP corresponds to a load balancing point in the adsorbent material, the $\mathrm{pH}$ values higher than PZ generate a negatively charged surface, while a pH lower than the PZ a positively charged surface. The adsorption capacity of an activated carbon is determined by its chemical composition and the distribution of loads on its surface (Menéndez, Illán-Gómez, \& Radovic, 1995; Appel, Ma, Dean, \& Kennelly, 2003; Izzeldin et al., 2013; Amaringo \& Hormanza, 2013; Andrade et al., 2018).

Therefore, this parameter is very important for establishing favorable conditions in terms of the $\mathrm{pH}$ value for the efficient removal of a given pollutant. In our work there are few references of potential zeta studies for activated carbon using exclusively cane bagasse, we used as reference the work reported by Izzeldin et al. (2013) where the adsorption of $\mathrm{Pb}^{2+}$ on nanotubes made with sugar cane bagasse is found a $\mathrm{pH}$ values 2 , increasing the number of groups negatively charged on the surface of the adsorbent resulting in a high adsorption of $\mathrm{Pb}^{2+}$, opposite at $\mathrm{pH}$ values below ZPC where the adsorption was lower due to the fact that metal ions compete with hydrogen ions for adsorption sites.

\section{Textural analysis of activated carbon}


Table 2 shows the textural results of BAC and CAC, first one had a lower specific surface area ( $\mathrm{S}_{\mathrm{BET}}$ ) than CAC with a difference of $32 \%$, it also showed a lower volume of pore (VT) than CAC. According to the result of the average pore diameter ( $D p)$, both carbons are in the mesoporous range $(2-50 \mathrm{~nm})$ near the micropores. Small pores are known to be the primary responsibility for carbon adsorption capacity. Based on these results it is hoped that the use of activated carbon from sugarcane bagasse could act as an efficient adsorbent when compared to commercial activated carbon.

Table 2. Textural parameters of BAC and CAC.

\begin{tabular}{|c|c|c|c|}
\hline \multirow{2}{*}{ Actived carbon } & SBET & $\mathbf{V}_{\mathbf{T}}$ & DP \\
\cline { 2 - 4 } & $\mathbf{m}^{\mathbf{2}} \mathbf{g}^{\mathbf{- 1}}$ & $\mathbf{( c m}^{\mathbf{3}} \mathbf{g}^{\mathbf{- 1}} \mathbf{)}$ & $\mathbf{n m}$ \\
\hline BAC & 914 & 0.5 & 3.6 \\
\hline CAC & 1353 & 0.9 & 3.9 \\
\hline
\end{tabular}

Figure $5 a$ and Figure $5 b$ contains the adsorption-desorption isotherms of the BAC and CAC samples, according to the IUPAC both materials are type I adsorption isotherms, which is characteristic of microporous solids. Finding that according to the determination of the diameter of the pores there is a combination of mesopores and micropores. The primary adsorption process is carried out in the narrow micropores and the secondary adsorption process is carried out in the widest pores. In addition, it has a hysteresis loop type $\mathrm{H}_{4}$, and indicate 
Tecnología y ţ⿻上丨

Ciencias $₫$ Agua
2022, Instituto Mexicano de Tecnología del Agua

Open Access bajo la licencia CC BY-NC-SA 4.0

(https://creativecommons.org/licenses/by-nc-sa/4.0/)

the presence of pores located between plates, with a uniform size and shape, which are characteristic of activated carbons (Leofanti, Padovan, Tozzola, \& Venturelli, 1998; Adinaveen et al., 2013; Andrade et al., 2018).
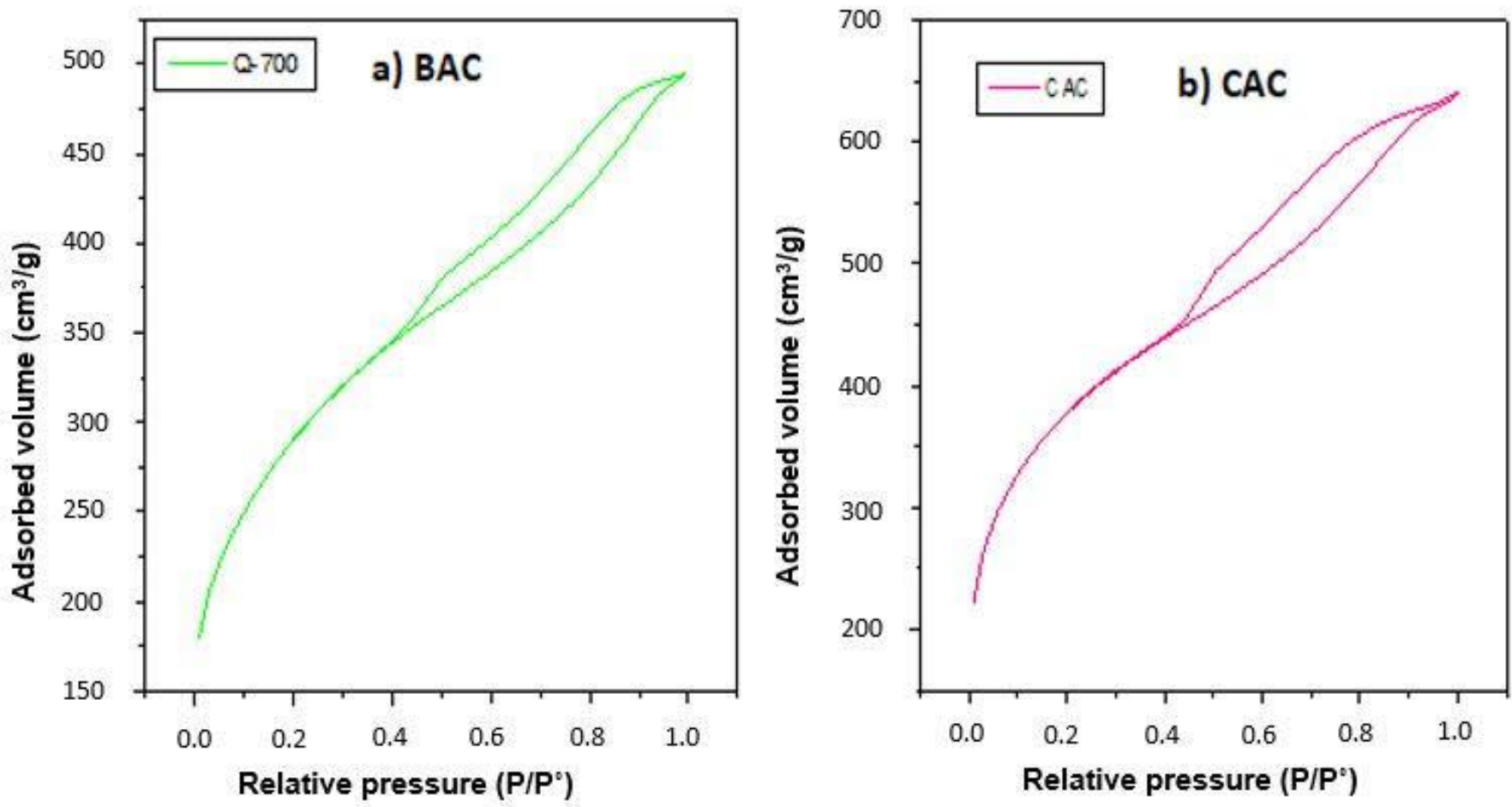

Figure 5. Adsorption-desorption isotherm of sugarcane bagasse activated carbon: a) BAC, b) CAC.

\section{Determination of greases and oils}


Domestic wastewater used for carbon assessment showed a content of 5 $293 \mathrm{mg} / \mathrm{l}$ of greases and oils on average. Based on the above guidelines, the body of water under analysis shows a high grease and oil content, within the range of 5 350, 5260 and $5270 \mathrm{mg} / \mathrm{l}$ (of the three repetitions performed). In accordance with the Official Mexican Standards (NOM001-ECOL-1996; NOM-002-ECOL-1996; NOM-003-ECOL-1997), the acceptable limit range for wastewater discharges in Mexico is 15 to 100 $\mathrm{mg} / \mathrm{l}$.

Greases and oils concentrations at different times during the adsorption process using activated carbon are shown in Figure 6 . The increased adsorption capacity is after $8 \mathrm{~h}$ of treatment for both carbons (BAC and CAC), decreasing the grease and oil concentration to $240 \mathrm{mg} / \mathrm{L}$ for CAC and $320 \mathrm{mg} / \mathrm{l}$ for BAC. In residence times of $8 \mathrm{~h}$, the grease and oil content was reduced by $96 \%$ (CAC) and $94 \%$ (BAC) respectively (Xue et al., 2014). 


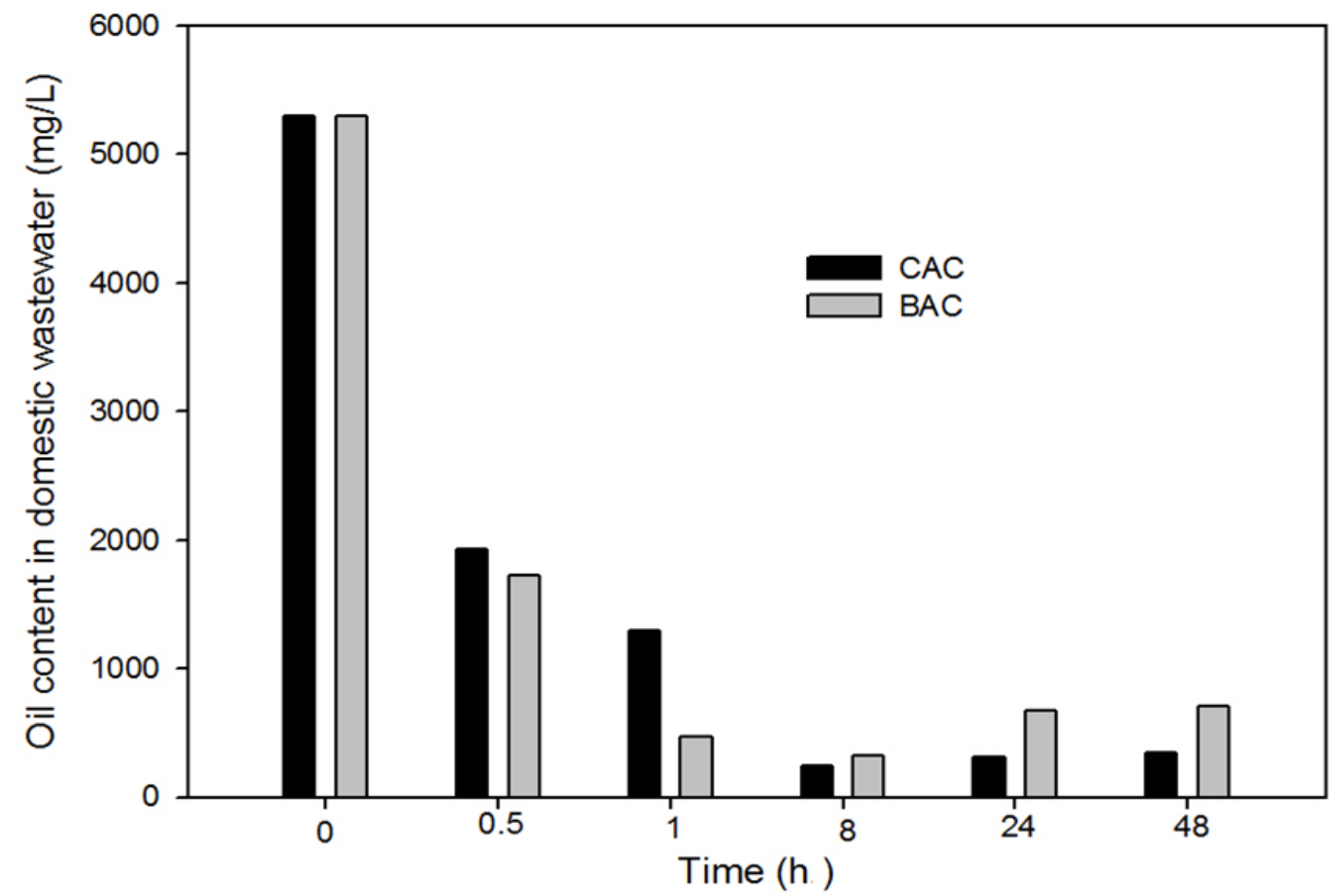

Figure 6. Grease and Oil content in domestic wastewater during adsorption process with BAC and CAC.

Decreased adsorption capacity after $8 \mathrm{~h}$ can be attributed to possible pore saturation in both carbons, as can be seen at 24 and 48 h, carbon depletes, due to the chemisorption of greases and oils in activated carbon, this process is not reversible, so the retained molecules will not be easily detached. The adsorption mechanism depends on the physical and/or chemical characteristics of the adsorbent, as well as the mass transport process (Xue et al., 2014). 
The study of kinetics involves the determination of the reaction rate as well as the mechanism of the adsorption process, in order to understand the interaction between activated carbon and grease and oil.

The adsorption process is shown in Figure 7, showing three main stages: 1) First stage, wastewater (greases and oils) is diffused from the liquid phase to the surface of the adsorbent (film diffusion stage); 2) In the second stage, wastewater greases and oils) enter the internal pores of the adsorbent from the surface of the adsorbent (intraparticle diffusion stage);3) Third stage, the adsorption process of grease and oil, enter the adsorption site (chemisorption). In these three stages, the resistance to adsorbate mass transfer is different; the maximum resistance to mass transfer, as well as the slowest step determines the adsorption processes. Adsorption balance quickly establishes adsorption sites (Xiaohong et al., 2018; Kuncoro et al., 2018a). 


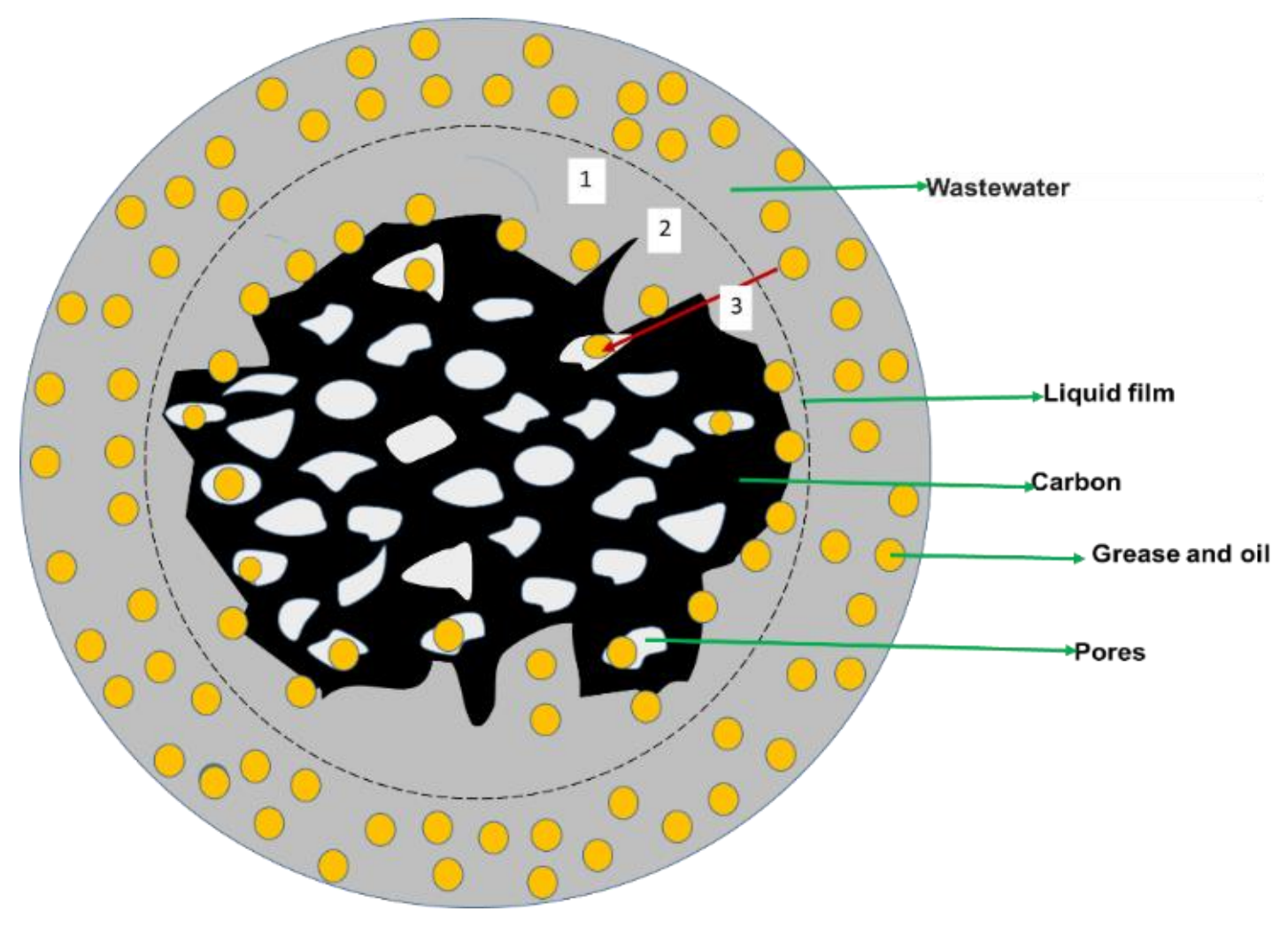

Figure 7. Scheme representing the physical mechanism of adsorption of grease and oils in activated carbon.

The kinetic model of the pseudo first order is based on the membrane diffusion theory and considers that the adsorption rate is proportional to the difference in the capacity of the adsorption of the balance and the amount of adsorption (Equation (2)). The pseudo-second order model assumes that the adsorption process includes chemisorption, adsorption on the surface, and diffusion in particles (Equation (3)). In the case of the intraparticle model, it proposes that the elimination of adsorbate should vary with the square root; therefore, the intraparticle diffusion coefficient (k_int) can be calculated with Equation (4) (Table 1). 
Teçnología y

Ciencias $₫$ Agua
2022, Instituto Mexicano de Tecnología del Agua

Open Access bajo la licencia CC BY-NC-SA 4.0

(https://creativecommons.org/licenses/by-nc-sa/4.0/)

In Table 3, the results of kinetic models are summarized, and experimental data for CAC and BAC are observed. The pseudo first order equation does not adjust the experimental data, the correlation value $\left(R^{2}\right)$, in both cases is 0.41 and 0.11 for CAC and BAC respectively. Table 3 show the results of the pseudo-second order kinetic model for CAC and BAC (t/qt vs. t), showing that experimental data for both activated carbons have a good fit with the kinetic model $\left(R^{2}=0.99\right.$ and $K_{2}=0.0002$ $\mathrm{g} / \mathrm{mg} \mathrm{min}$ ) achieving at eight hours a decrease in greases and oils from 240 and $320 \mathrm{mg} / \mathrm{g}$ for CAC and BAC, respectively. From the results, it can be inferred that this model represents the adsorption of greases and oils (BAC and CAC).

Table 3. Parameters of the kinetics models for the adsorption of greases and oils.

\begin{tabular}{|l|c|c|c|}
\hline \multicolumn{1}{|c|}{ Model } & Parameters & BAC & CAC \\
\hline Experimental & $\mathrm{q}_{\mathrm{e}}(\mathrm{mg} / \mathrm{g})$ & 320 & 240 \\
\hline \multirow{2}{*}{ Pseudo first order } & $\mathrm{K}_{1} / \mathrm{min}^{-1}$ & 0.0002 & 0.0005 \\
\cline { 2 - 4 } & $R^{2}$ & 0.1171 & 0.4086 \\
\hline \multirow{2}{*}{ Pseudo second order } & $\mathrm{K}_{2}(\mathrm{~g} / \mathrm{mg} \cdot \mathrm{min})$ & 0.0002 & 0.0002 \\
\cline { 2 - 4 } & $\mathrm{R}^{2}$ & 0.9998 & 0.9999 \\
\hline \multirow{2}{*}{ Intraparticle diffusion } & $\mathrm{K}_{\mathrm{int}}\left(\mathrm{mg} / \mathrm{g} \mathrm{min}^{0.5}\right)$ & 3.68 & 3.94 \\
\cline { 2 - 4 } & $R^{2}$ & 0.792 & 0.671 \\
\hline
\end{tabular}


According to the research of Yun et al. (2010), which agrees that the pseudo second order model better represents the adsorption process using the sugarcane bagasse as an adsorbent, confirming that the adsorption rate is controlled by a chemisorption process. The adsorption mechanism depends on the physical and/or chemical characteristics of the adsorbent as well as the mass transport process (Xue et al., 2014).

Table 3 shows that experimental data do not fit to a straight line in the intra-particle kinetic diffusion model, adsorption of both carbons is better represented by a quadratic model, nevertheless correlation coefficients for BAC $\left(R^{2}=0.792\right)$ and CAC $\left(R^{2}=0.671\right)$ are not appropriate to fit the data to quadratic expressions. Also other studies use activated carbon of sugarcane bagasse as an adsorbent, this result indicates this is then model involved in the adsorption process (Almeida et al., 2019).

From results obtained with the kinetic adsorption study, it can be concluded that adsorption of greases and oils in both activated carbons follows a second-order kinetics. This model predicts that the adsorption process occurs in chemisorption and hay a transient period.

The experimental data were plotted following the Equation (5) (Table 1) and adjusted to a straight line $(y=m x+b)$, and it was represented according to the Lineal Langmuir model as followed:

$\frac{C_{e}}{q_{e}}=\frac{C_{e}}{q_{m}}+\frac{1}{q_{m} K_{L}}$ 
Where the maximum adsorption capacity is obtained from the slope value of the line $\left(1 / \mathrm{q}_{\mathrm{m}}\right)$ for $\mathrm{BAC} ; y=320 x+4 \times 10^{-13}$ and considering the next information:

$y=\frac{C_{e}}{q_{e}}$

$x=C_{e}$

$\frac{1}{q_{m}}=320$

$q_{m}=\frac{1}{320}=0.003125$

$\frac{1}{q_{m} K_{L}}=4 \times 10^{-13}$

$K_{L}=\frac{1}{\left(4 \times 10^{-13}\right)(0.003125)}=8.0 \times 10^{14}$

The same procedure was done for CAC using the next equation for representing the adjustment of experimental data; $y=240 x+1 \times 10^{-12}$, and all summary results are shown in the Table 4. Reporting the adjustment 
Tecnología y

Ciencias $₫$ Agua
2022, Instituto Mexicano de Tecnología del Agua

Open Access bajo la licencia CC BY-NC-SA 4.0

(https://creativecommons.org/licenses/by-nc-sa/4.0/)

of the experimental data of the adsorption of grease and oil in BAC and CAC to the Langmuir model, and both cases fit the model with $R^{2}=1.0$.

Table 4. Adsorption isotherm parameters for BAC and CAC.

\begin{tabular}{|c|c|c|c|}
\hline Isotherm & Parameter & BAC & CAC \\
\hline \multirow{3}{*}{ Langmuir } & $\mathrm{qm}(\mathrm{mg} / \mathrm{g})$ & 0.003125 & 0.004166 \\
\cline { 2 - 4 } & $\mathrm{K}(\mathrm{l} / \mathrm{mg})$ & $8 \times 10^{14}$ & $2 \times 10^{14}$ \\
\cline { 2 - 4 } & $R^{2}$ & 1.0 & 1.0 \\
\hline \multirow{3}{*}{ Freundlich } & $n$ & 3.92 & 4.69 \\
\cline { 2 - 4 } & $\mathrm{K}_{\mathrm{f}}(\mathrm{l} / \mathrm{g})$ & 1.21 & 1.10 \\
\cline { 2 - 4 } & $R^{2}$ & 0.76 & 0.85 \\
\hline
\end{tabular}

The Langmuir model considers that the adsorption carried out homogeneously on the surface forming a monolayer where the interaction with the adsorbent material occurs.

The Freundlich isotherm considers that adsorption is carried out in the form of a multilayer in which the energy is distributed in the active sites and it considers that occurs an interaction between the adsorbed molecules (Hyung-Keun et al., 2015).

Table 4 shows the correlation of the experimental data with the Freundlich model lineal (Table 1, Equation (6)), and lineal equation is: 
Tecnología y

Ciencias $₫$ Agua
2022, Instituto Mexicano de Tecnología del Agua

Open Access bajo la licencia CCBY-NC-SA 4.0

(https://creativecommons.org/licenses/by-nc-sa/4.0/)

$q e=\frac{1}{n} \log C e+\log K f$

Adjusting the straight line of the BAC experimental data, gives the following equation: $y=0.2545 x+0.0838$. In the case of the CAC, the equation representing the Freundlich Model is: $y=0.2128 x+0.0434$

Clearing the values results in the Freundlich constant $\left(\mathrm{K}_{\mathrm{f}}\right)$ and consisting of the energy sites $(n)$ as shown in the Table 4 . The values of $R^{2}$ are low for both activated carbon despite the fact that the adsorption in CAC is adjusted with an $R^{2}=0.85$ and $\mathrm{BAC}$ an $R^{2}=0.76$.

Analyzing similar studies that used sugarcane bagasse to eliminate grease and oils/hydrocarbons, we can observe the importance of particle size, carbon granulometry and contact time, system type, stirring speed and other factors that influence the adsorption capacity of activated carbon from sugar cane bagasse or using natural cane bagasse without any treatment (Table 5).

Table 5. Characteristics of the different adsorbent. *\% Adsorption.

\begin{tabular}{|c|c|c|c|c|c|c|}
\hline Adsorbent & Adsorbate & $\begin{array}{c}\text { Type of } \\
\text { system }\end{array}$ & Co (mg/l) & Time & *\% A & Reference \\
\hline $\begin{array}{c}\text { Sugarcane } \\
\text { bagasse }\end{array}$ & $\begin{array}{c}\text { Synthetic } \\
\text { water } \\
\text { (emulsified } \\
\text { oil) }\end{array}$ & Stirred Tank & $20-212$ & $5-10 \mathrm{~min}$ & $90 \%$ & $\begin{array}{l}\text { Almeida et al. } \\
2019\end{array}$ \\
\hline
\end{tabular}


Tecnología y

Ciencias $₫$ Agua
2022, Instituto Mexicano de Tecnología del Agua

Open Access bajo la licencia CC BY-NC-SA 4.0

(https://creativecommons.org/licenses/by-nc-sa/4.0/)

\begin{tabular}{|c|c|c|c|l|l|l|}
\hline $\begin{array}{c}\text { Natural cane } \\
\text { bagasse }\end{array}$ & $\begin{array}{c}\text { Greases and } \\
\text { oils }\end{array}$ & $\begin{array}{c}\text { Filled } \\
\text { column }\end{array}$ & 992.00 & $12 \mathrm{~h}$ & $98.5 \%$ & $\begin{array}{l}\text { Martinez_Nodal } \\
\text { et al., } 2014\end{array}$ \\
\hline $\begin{array}{c}\text { Natural cane } \\
\text { bagasse }\end{array}$ & $\begin{array}{c}\text { Greases and } \\
\text { oils }\end{array}$ & $\begin{array}{c}\text { Filled } \\
\text { column }\end{array}$ & 25.21 & $12-32 \mathrm{~h}$ & $83.58 \%$ & $\begin{array}{l}\text { Leiva-Mass et } \\
\text { al., } 2012\end{array}$ \\
\hline $\begin{array}{c}\text { Bagasse } \\
\text { hydrophobed } \\
\text { with } \\
\text { surfactant }\end{array}$ & hydrocarbons & $\begin{array}{c}\text { Filled } \\
\text { column } \\
\text { discontinues }\end{array}$ & 300 & $12 \mathrm{~h}$ & $90 \%$ & $\begin{array}{l}\text { Rincones et al., } \\
2015\end{array}$ \\
\hline $\begin{array}{c}\text { Sugarcane } \\
\text { bagasse }\end{array}$ & $\begin{array}{c}\text { Wastewater } \\
\text { (greases and } \\
\text { oils })\end{array}$ & $\begin{array}{c}\text { Batch with } \\
\text { constant } \\
\text { agitation }\end{array}$ & $5260-5270$ & $8 \mathrm{~h}$ & $94 \%$ & This word \\
\hline
\end{tabular}

Martinez-Nodal et al. (2014) used as a bioadsorbent bagasse of natural cane and as an adsorbate, wastewater containing grease and oils at a concentration of $992.00 \mathrm{mg} / \mathrm{l}$, the experimentation was performed in a continuous flow system $(1 \mathrm{l} / \mathrm{h}$ ) through a fixed bed (59 $997 \mathrm{~g}$ of cane bagasse), obtaining an adsorption of $98.5 \%$, in a time of 12 hours. Almeida et al. (2019) used synthetic waters with emulsified petroleum, and they conclude that a phase balance is achieved at 5 minutes of contact and elimination rates of more than $90 \%$ were obtained using oil concentrations up to $212.0 \mathrm{mg} / \mathrm{l}$. The maximum adsorption capacity was $207.3 \mathrm{mg} / \mathrm{g}$, at pH 4, $110 \mathrm{rpm}$ at $303 \mathrm{~K}$. On the other hand, Rincones et al. (2015) use the hydrofobated sugarcane bagasse with surfactant for the removal of petroleum hydrocarbons in oily waters, hydrocarbon removal efficiencies of more than $90 \%$ were obtained to the point of saturation of the bed in the adsorption column, which demonstrate the applicability. Bed adsorption capacity and operating time increased at low 
feed rates of the tributary and higher bed height in the studied range. From what we can see from this experimental study for the treatment of greases and oils with activated carbon cane bagasse or natural cane bagasse is feasible. In accordance with the Mexican Official Standards (NOM-001-ECOL-1996; NOM-002-ECOL-1996; NOM-003-ECOL-1997), the acceptable range of limits for wastewater discharges is 15 to 100 $\mathrm{mg} / \mathrm{l}$, so this research can be continued in the future, coupling the Batch system continuously with a fixed bed with natural cane bagasse to decrease concentrations, greases and oils in wastewater.

In the case of sugarcane production in Tabasco, it is a serious problem; sugar cane is burned before harvest in order to reduce the amount of leaf (unused) and thus facilitate the zafra and transport of the product to the sugar mill. How well identified burning cane bagasse is generates highly polluting atmospheric emissions such as dioxins, which can affect the health of the inhabitants. So, this study contains interesting results and aims to give added value to a material considered as a waste.

\section{Conclusions}


Tecnología y

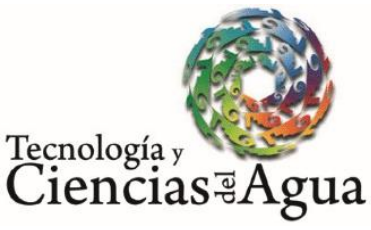

2022, Instituto Mexicano de Tecnología del Agua

Open Access bajo la licencia CC BY-NC-SA 4.0

(https://creativecommons.org/licenses/by-nc-sa/4.0/)

Sugarcane bagasse as a raw material in the production of activated carbon results in a material that allows the removal of $94 \%$ of the oils contained in domestic wastewater, which can be compared to that of a commercial coal (96\%). Absorption capacity is directly related to pore size, a combination of micro and mesopores in materials synthesized allows interaction with greases and oils. The specific area found indicates the high number of pores available to interact with wastewater contaminants.

According to the isoelectric point the BAC tends to agglomerate to $\mathrm{pH}$ about 2.5, means that a value close to neutrality tends to be dispersed, the adsorption kinetics studied follow a pseudo second order model, this assumes that the adsorption process occurs in different stages and adsorption is controlled on the surface, in addition there is the diffusion in the particles of activated carbon and chemisorption. From this point of view, its use as an adsorbent can add value to an industrial waste, such as sugarcane bagasse, which presents difficulties for its final confinement.

\section{Acknowledgements}

The authors want to acknowledge the University Juarez Autonomy of Tabasco for the financial support in the development of this research (PFI 10-DAIA-IB-2016); to Fabiana del Carmen Hernandez Sanchez for her support in the laboratory analysis; to Anabel Gonzalez Dias for her support in the SEM analysis, and Richart Falconi Calderon for the X-ray analysis. 
Tecnología y

Ciencias $₫$ Agua
2022, Instituto Mexicano de Tecnología del Agua

Open Access bajo la licencia CC BY-NC-SA 4.0

(https://creativecommons.org/licenses/by-nc-sa/4.0/)

\section{References}

Acosta, G. E. (2013). Partículas hidrofobadas de bagazo de caña de azúcar para el tratamiento de hidrocarburos en agua. Saber, 25(1), 97-103. Recovered from http://ve.scielo.org/scielo.php?script=sci_arttext\&pid=S1315$01622013000100011 \&$ Ing=es\&tIng $=e s$

Adinaveen, T., Kennedy, L., Vijaya, J., \& Sekaran, G. (2013). Studies on structural, morphological, electrical and electrochemical properties of activated carbon prepared from sugarcane bagasse. Journal of Industrial and Engineering Chemistry, 19, 1470-1476. Recovered from http://dx.doi.org/10.1016/j.jiec.2013.01.010

Almeida, F., Meili, L., Soletti, J., Esquerre, K., Ribeiro, L., \& De-FariasSilva, C. (2019). Oil produced water treatment using sugarcane solid residue as biosorbent. Revista Mexicana de Ingeniería Química, 18(1), 27-38.

Recovered

from

https://doi.org/10.24275/uam/izt/dcbi/revmexingquim/2019v18n1/A Imeida

Amaringo, V. F. A., \& Hormaza, A. A. (2013). Determination of the point of zero charge and isoelectric point of two agricultural wastes and their application in the removal of colorants. Revista de Investigación Agraria y Ambiental, 4(2), 27-36. Recovered from http://dx.doi.org/10.22490/21456453.982

Andrade, S., Veloso, C., Fontan, R., Bonomo, R., Santos, L., Brito, M., \& Diniz, G. (2018). Chemical-activated carbon from coconut (Cocos nucifera) endocarp waste and its application in the adsorption of $B$ - 
Tecnología y

Ciencias $₫$ Agua
2022, Instituto Mexicano de Tecnología del Agua

Open Access bajo la licencia CC BY-NC-SA 4.0

(https://creativecommons.org/licenses/by-nc-sa/4.0/)

lactoglobulin protein. Revista Mexicana de Ingeniería Química, 17, 2, 463-475. Recovered from DOI:

https://doi.org/10.24275/10.24275/uam/izt/dcbi/revmexingquim/20 18v17n2/Andrade

Appel, C., Ma, L., Dean, R., \& Kennelly, E. (2003). Point of zero charge determination in soils and minerals via traditional methods and detection of electroacoustic mobility. Geoderma, 113(1-2), 77-93. Recovered from http://dx.doi:10.1016/S0016-7061 (02)00316-6

Contreras, J., Fuenmayor, H., Colina, M., Díaz, A., Fernández, N., Pérez, M. J., \& Colin, G. (2008). Capacity adsorptive activated carbon prepared from sugar cane bagasse for adsorption of phenol, 2chlorophenol, 2-nitrafenol, 2, 4-dimethylphenol. Science, 16(1), 111121.

Recovered

from

http://www.produccioncientifica.luz.edu.ve/index.php/ciencia/article/ view/9835/9822

Corral-Escárcega, M., Ruiz-Gutiérrez, M., Quintero-Ramos, A., MeléndezPizarro, C., Lardizabal-Gutiérrez, D., \& Campos-Venegas, K. (2017). Use of biomass-derived from pecan nut husks (Carya illinoinensis) for chromium removal from aqueous solutions. Column modeling and adsorption kinetics studies. Revista Mexicana de Ingeniería Química, 16(3), 939-953.

Recovered

from

https://www.redalyc.org/articulo.oa?id=62053304021

Cruz, G., Ainassaari, K., Gómez, M., Solís, J., \& Keiski, R. (2018). Microporous activation carbon made of sawdust from two forestry species for adsorption of methylene blue and heavy metals in aqueous 
system - case of real polluted water. Revista Mexicana de Ingenieńa Química 17(3), 847-861. Recovered from https://doi.org/10.24275/uam/izt/dcbi/revmexingquim/2018v17n3/

Freundlich, H.M.F. (1906). Uber die adsorption in losungen. Zeitschrift fur Physikalische Chemie 57, 385-471. URL: https://openlibrary.org/books/OL15094118M/Über_die_Adsorption_i n_Lösungen.

Garg, V. K., Amita, M., Kumar, R., \& Gupta, R. (2004). Basic dye (Methylene Blue) removal from simulated wastewater by adsorption using Indian rosewood sawdust. Dyes Pigments, 63, 243-250. Recovered from https://doi.org/10.1016/j.dyepig.2004.03.005

Garoma, T. S., \& Badriyha, B. (2010). Removal of cadmium, copper and zinc from solution by active carbon impregnated with 8hydroxyquinoline. Journal of Environmental Science and Engineering, 4(5), 14-21.

Ghani, Z. A., Yusoff, M. S., Zaman, N. Q., Zamri, M. F., \& Andas, J. (2017). Optimization of preparation conditions for activated carbon from banana pseudo-stem using response surface methodology on removal of color and COD from landfill leachate. Waste Management, 62, 177-187, DOI: 10.1016/j.wasman.2017.02.026

Goswami, M., \& Phukan, P. (2017). Enhanced adsorption of cationic dyes using sulfonic acid modified activated Carbon. Journal of Environmental Chemical Engineering, 5, 3508-3517. Recovered from https://doi.org/10.1016/j.jece.2017.07.016 
Hajira, T., Muhammad, S., Nasir, A., Uzma, H., \& Tahreem, A. (2016). Application of natural and modified sugar cane bagasse for the removal of dye from aqueous solution. Journal of Saudi Chemical Society, 20, S115-S121. Recovered from http://dx.doi.org/10.1016/j.jscs.2012.09.007

Ho, Y. S., \& McKay, G. (1998). Kinetic models for adsorption of dye from aqueous solution by wood. Process Safety and Environmental Protection, 76, part B. Recovered from https://doi.org/10.1205/095758298529326

Hyung-Keun, C., Woon-Hoe, K., Jeongwon, P., Jinwoo, C., Tae-Young, J. and Pyung-Kyu Park. (2015). Application of Langmuir and Freundlich isotherms to predict adsorbate removal efficiency or required amount of adsorbent. Journal of Industrial and Engineering Chemistry 28, 241 246. https://doi.org/10.1016/j.jiec.201502.021.

Islam, M. A., Ahmed, M. J., Khanday, W. A., Asif, M., \& Hameed, B. H. (2017). Mesoporous activated coconut shell-derived hydrochar prepared via hydrothermal carbonization- $\mathrm{NaOH}$ activation for methylene blue adsorption. Journal of Environmental Management, 203, 237-244. DOI: 10.1016/j.jenvman.2017.07.029

Izzeldin, A. A. H., Bice, S. M., Ngilaa, J. C., \& Nyamoria, V. O. (2013). Adsorption studies of aqueous $\mathrm{Pb}$ (II) onto a sugarcane bagasse/multiwalled carbon nanotube composite. Physics and Chemistry of the Earth, 66, 157-166. Recovered from http://dx.doi.org/10.1016/j.pce.2013.08.006 
Kuncoro, E. P., Dwi, R. M. I., Handoko, D., Oktiani, R. F., \& Septya, K. H. (2018a). Characterization, kinetic, and isotherm data for adsorption of $\mathrm{Pb}+2$ from aqueous solution by adsorbent from mixture of bagassebentonite. Data in Brief, 16, 622-629. Recovered from https://doi.org/10.1016/j.dib.2017.11.098

Kuncoro, E. P., Mitha-Isnadina, D. R., Darmokoesoemo, H., Dzembarahmatiny, F., \& Kusuma, H. S. (2018b). Characterization and isotherm data for adsorption of $\mathrm{Cd}^{2+}$ from aqueous solution by adsorbent from mixture of bagasse-bentonite. Data Brief, 16, 354360. DOI: $10.1016 / j$.dib.2017.11.060

Lagergren, S. (1898). About the theory of so-called adsorption of soluble substances. Kungliga Svenska Vetenskapsakademiens, 24, 1-39.

Langmuir, I. (1918). The adsorption of gases on plane surface of glass, mica and platinum. Journal of the American Chemical Society 40, 1361-1403. DOI: $10.1021 / j a 02242 a 004$.

Leiva-Mas, J., Martínez-Nodal, P. C., Esperanza-Pérez, G., RodríguezRico, I. L., \& Gordiz-García, C. E. (2012). Absorción de hidrocarburos en columnas rellenas con bagazo: una solución sostenible. ICIDCA. Sobre los Derivados de la Caña de Azúcar, 46(3), 36-44. Recovered from https://www.redalyc.org/articulo.oa?id=2231/223124988005.

Leofanti, G., Padovan, M., Tozzola, G., \& Venturelli, B. (1998). Surface area and pore texture of catalysts. Catalisys Today, 41, 207-219. DOI: 10.1016/S0920-5861(98)00050-9 
Tecnología y

Ciencias ฐึgua
2022, Instituto Mexicano de Tecnología del Agua

Open Access bajo la licencia CC BY-NC-SA 4.0

(https://creativecommons.org/licenses/by-nc-sa/4.0/)

Leyva-Ramos, R., Díaz-Flores, P. E., Guerrero-Coronado, R. M., MendozaBarrón, J., \& Aragón-Piña, A. (2004). Adsorption of Cd (II) in aqueous solution on different types of activated carbon fibers. Journal of the Chemical Society of Mexico, 48, 196-202. Recovered from http://www.scielo.org.mx/pdf/rsqm/v48n3/v48n3a3.pdf

Leyva-Ramos, R., Rivera-Utrilla, J., Medellin-Castillo, M. A., \& SánchezPolob, M. (2010). Kinetic modeling of fluoride adsorption from aqueous solution onto bone char. Chemical Engineering Journal, 158(3), 458-467. DOI: 10.1016/j.cej.2010.01.019

Martínez-Nodal, P., Rodríguez, R. I., Esperanza-Pérez, G., \& Leiva-Mas, J. (2014). Caracterización y evaluación del bagazo de caña de azúcar como biosorbente de hidrocarburos, Revista Afinidad, 71, 565.

Mateo-Sánchez, J. (2011). Preparation of activated charcoal from sugar cane bagasse (Bachelor's Thesis in Chemical Engineering). Academic Division of Engineering and Architecture, Universidad Juárez Autónoma de Tabasco, Tabasco, México.

Menéndez, J., Illán-Gómez, C., \& Radovic, R. (1995). On the difference between the isoelectric point and the point of zero charge of carbons. Carbon, 33(11), 1655-1659. Recovered from https://ac.els-cdn.com

Meza, J. C., Lomascolo, A., \& Laurence, C. (2006). Assessment of the bagasse of sugar cane. Biotechnologies at the Service of the Paper Industry Mexico, Recovered from https://es.scribd.com/document/47887927/valorizacion-del-bagazode-cana-de-azucar-industria-papelera 
Norma Oficial Mexicana, NOM-001-ECOL-1996. Diario Oficial de la Nación, México. Recovered

from http://www.conagua.gob.mx/CONAGUA07/Publicaciones/Publicacion es/SGAA-15-13.pdf

Norma Oficial Mexicana, NOM-002-ECOL-1996. Diario Oficial de la Nación, México. Recovered from http://www.conagua.gob.mx/CONAGUA07/Publicaciones/Publicacion es/SGAA-15-13.pdf

Norma Oficial Mexicana, NOM-003-ECOL-1997. Diario Oficial de la Nación, México.

http://www.conagua.gob.mx/CONAGUA07/Publicaciones/Publicacion es/SGAA-15-13.pdf

Ramavandi, B., Asgari, G., Faradmal, J., Sahebi, S., \& Roshani, B. (2014). Abatement of $\mathrm{Cr}$ (VI) from wastewater using a new adsorbent, cantaloupe peel: Taguchi L16 orthogonal array optimization. Korean Journal of Chemical Engineering, 31(12), 2207-2214. DOI: $10.1007 / \mathrm{s} 11814-014-0172-6$

Ramírez-Rodríguez, A., Reyes-Ledezma, J., Chávez-Camarillo, G., Cristiani-Urbina, E., \& Morales-Barrera, L. (2018). Cyclic biosorption and desorption of acid red 27 onto Eichhornia crassipes leaves. Revista Mexicana de Ingeniería Química, 17(3), 1121-1134. Recovered from https://doi.org/10.24275/uam/izt/dcbi/revmexingquim/2018v17n3/ Ramirez

Rincones-Poyer, F., Valladares, S. M., Danglad-Flores, J. A., \& SalazarPalencia, V. (2015). Adsorción de hidrocarburos de petróleo en agua 
mediante una columna empacada con bagazo de caña de azúcar. Saber, 27(3), 441-453. Recovered from

http://ve.scielo.org/scielo.php?script=sci_arttext\&pid=S1315-

$01622015000300010 \&$ Ing =es\&tIng =es

Saad, S. A., Isa, K. Md., \& Bahari, R. (2010). Chemically modified sugarcane bagasse as a potencially low-cost bisorbent for dye removal. Journal of Desalination, 264(1-2), 123-128. DOI: 10.1016/j.desal.2010.07.015

Velázquez-Trujillo, A., Bolaños-Reynoso, E., \& Pliego-Bravo, Y. S. (2010). Optimización de la producción de carbón activado a partir de bambú. Revista Mexicana de Ingeniería Química, 9(3), 359-366. Recovered from

http://www.scielo.org.mx/scielo.php?script=sci_arttext\&pid=S1665$27382010000300010 \&$ Ing=es\&tIng=es

Weber, W. J., \& Morris, J. C. (1963). Kinetics of adsorption on carbon from solutions. Journal of the Sanitary Engineering Division, 98, 31-60. Recovered from

https://cedb.asce.org/CEDBsearch/record.jsp?dockey=0013042

Xiaohong, W., Chenglong, J., Bingxia, H., Yingying W., Chen, H., \& Jingbo, W. (2018). Carbon composite lignin-based adsorbents for the adsorption of dyes. Journal of Chemosphere, 206, 587-596. Recovered from https://doi.org/10.1016/j.chemosphere.2018.04.183 Xue, T., Gao, Y., Zhang, Z., Umar, A., Yan, X., Zhan, X., Guo, Z. , \& Wang, Q. (2014). Adsorption of acid red from dye wastewater by $\mathrm{Zn}_{2} \mathrm{Al}-\mathrm{NO}_{3}$ LDHs and the resource of adsorbent sludge as nanofiller for 
polypropylene. Journal of Alloys and Compounds, 587, 99-104. Recovered from https://doi.org/10.1016/j.jallcom.2013.10.158

Yun, X., Liu, D., \& Zhang, L. (2010). Enhanced adsorption of methylene blue by EDTAD modified sugarcane bagasse and photocatalytic regeneration of the adsorbent. Desalination, 259, 187-191. DOI: 10.1016/j.desal.2010.04.008 